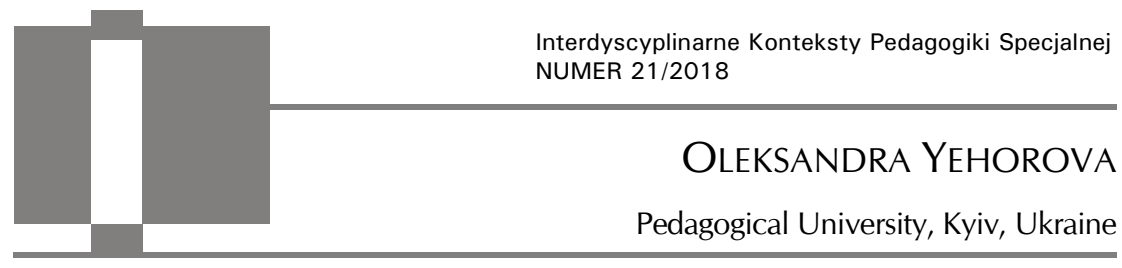

\title{
Perspectives of Civic Upbringing as in Non formal Education
}

ABSTRACT: Oleksandra Yehorova, Perspectives of Civic Upbringing as in Non formal Education. Interdyscyplinarne Konteksty Pedagogiki Specjalnej, nr 21, Poznań 2018. Pp. 305-321. Adam Mickiewicz University Press. ISSN 2300-391X. DOI: https://doi. org/10.14746/ikps.2018.21.16

The article covers the theoretical aspects and importance of civic education in its broad sense nowadays and analyzes its role, tasks, the after-school programs, best experiences and practices of after-school education in the United States in the field of civic education and upbringing. In the article civic education in the framework of U.S. out-of-school time is substantiated as a systematic object in its substantive and procedural aspects, which aims to form national, universal human values, civic activity and competencies required in the XXI century. It has been established that civic education and upbringing has been integrated in the secondary school and out-of-school education curriculum and practice, is considered as a priority task for education at the present stage in the United States and is a perspective area for nonformal education in Ukraine and beyond.

KEY WORDS: civic education/upbringing, competences of the XXI century, nonformal education, after-school education, out-of-school education.

The task of developing recommendations on the development of a system of non-formal education in Ukraine based on experience and best practices in the United States includes the analysis and comparison of the state of non-formal education in the field of civic 
education as a special area of non-formal education in both countries. First of all, we would like to note that the issues of development of civic education in general and non-formal education in particular, are closely linked with a separate direction of pedagogical science and practice - civic education (upbringing). It is known that this was and is one of the most characteristic features of out-ofschool education in the United States. In Ukraine, the direction of "civic education" (civics) has become very relevant at the present moment, when the problem of forming the civic competence of modern children and youth is actualized. To achieve this goal, much attention is paid to studying the experience and successful international practices of other countries, in particular the United States as a country with well-developed system of non-formal education.

It is established that at the present stage there, civic education is considered rather broadly. According to T. Wagner, one of the Directors of the Leadership Change Group at the Harvard Graduate School of Education Development, there is "convergence" among the skills required in the global economy and those skills that contribute to the security and prosperity of democracy ${ }^{1}$. The Guardian of Democracy reports, based on various studies, that civic education "not only promotes civic knowledge and skills, but also promotes learning" competencies of the 21st century"2. "The Crucible Moment: College Learning and Democracy's Future" paper states:

1 Yehorova O. Hromadyanske vykhovannya yak spetsialnyi napryam pozashkilnoyi osvity // Pedahohichni nauky Shidnoyevropeiskoho natsionalnoho universytetu imeni Lesi Ukrayinky. zb. nauk. st. - Lutsk, 2017. - Seriia 2 (351). - pp. 8-14.; Yehorova O. Hromadyanske vykhovannya yak spetsialnyi napryam pozashkilnoyi osvity // Pedahohichni nauky Shidnoyevropeiskoho natsionalnoho universytetu imeni Lesi Ukrayinky. zb. nauk. st. - Lutsk, 2017. - Seriia 2 (351). - pp. 8-14.

${ }^{2}$ Gould J. Guardians of Democracy: The Civic Mission of Schools / J. Gould // Philadelhia: Lenore Annerberg Institute of Civics of the Annenberg Public Policy Center, Campaign for the Civic Mission of Schools. - Philadelhia, 2011. - 159 p.; Yehorova O. Hromadyanske vykhovannya yak spetsialnyi napryam pozashkilnoyi osvity // Pedahohichni nauky Shidnoyevropeiskoho natsionalnoho universytetu imeni Lesi Ukrayinky. zb. nauk. st. - Lutsk, 2017. - Seriia 2 (351). - pp. 8-14. 
"A socially strong and economically developed American democracy ... needs knowledgeable, engaging, open and socially responsible people. who are committed to the common good and practice democracy "...civil education needs to be an integrative component of every level of education..."3. The National Task Force on Civic Learning and Democratic Engagement also mentioned the change of the paradigm of modern national civic education as a priority education direction; historical and contemporary understanding of democratic values; attraction of different points of view and opinions of different layers of population, focus on collective decision of civil problems; orientation at higher levels of civic education, skills, values of each student and university student ${ }^{4}$. At the same time, K. Popadyuk points out that the National Council for the Education of the United States of America (NCSS), a professional association of educators in the field of civic education in the world and an umbrella organization that brings together organizations in 50 states of America and 69 organizations from other countries, the primary task of civic education is to help students "adopt transparent and well-considered solutions for public welfare as citizens of a culturally diverse, democratic society in an interconnected world"5.

${ }^{3}$ Yehorova O. Hromadyanske vykhovannya yak spetsialnyi napryam pozashkilnoyi osvity // Pedahohichni nauky Shidnoyevropeiskoho natsionalnoho universytetu imeni Lesi Ukrayinky. zb. nauk. st. - Lutsk, 2017. - Seriia 2 (351). - pp. 8-14; Yehorova O. Hromadyanske vykhovannya yak spetsialnyi napryam pozashkilnoyi osvity // Pedahohichni nauky Shidnoyevropeiskoho natsionalnoho universytetu imeni Lesi Ukrayinky. zb. nauk. st. - Lutsk, 2017. - Seriia 2 (351). - pp. 8-14.

4 Yehorova O. Hromadyanske vykhovannya yak spetsialnyi napryam pozashkilnoyi osvity // Pedahohichni nauky Shidnoyevropeiskoho natsionalnoho universytetu imeni Lesi Ukrayinky. zb. nauk. st. - Lutsk, 2017. - Seriia 2 (351). - pp. 8-14; Yehorova O. Hromadyanske vykhovannya yak spetsialnyi napryam pozashkilnoyi osvity // Pedahohichni nauky Shidnoyevropeiskoho natsionalnoho universytetu imeni Lesi Ukrayinky. zb. nauk. st. - Lutsk, 2017. - Seriia 2 (351). - pp. 8-14.

${ }^{5}$ Popadyuk K. Specificity of the adaptation of the American information in the sphere of civic education and upbrining/ K. Popadyuk / / Actual problems of civic education and upbrining: Ukrainian and foreign experiences: materials of the I scientific and practical conference, 19 June 2013. / National. Univ. “Ostrozka Akademia”, non-governmental organization "Center for Democratic Leadership"; [Відп. Еd. 
That is, there is an understanding of the need to preserve and convey common values and ideals, the important role of civic education in this process, and the need to adapt the program to current needs. So nonformal education can help in this, support selfknowledge, the education of tolerance, openness to the new, the ability to co-operate with different people ${ }^{6}$. Thus, in modern pedagogical science, we can distinguish two approaches to the meaning of the concept of civic education. First, narrow one - teaching as a separate school subject. Secondly, the broad significance of the process and the result of preparing of the younger generation. As for the subject of our study, we mean civic education in the broad sense as a special field of non formal education. At the same time, this program, besides knowledge of political and state systems and mechanisms of their work and democratic principles, also contains debates on application.

The C Programming for the Twenty-First Century Civic Learning and Democratic Engagement points out the values that civic and historical education should bring: respect for freedom and human dignity, openness, empathy, tolerance, responsibility for universal good, justice, ethical integrity, equality. Particular attention is paid to such a category as "actions in a team", namely: compromise and mutual respect, solving public problems involving different parties, integrating knowledge, skills and values in action, moral behavior, orientation in political systems and processes ${ }^{7}$.

O. S. Batishcheva]. - Ostrog, 2013. - 234 p.; Popadyuk K. The formation of the civic education in Ukraine. A glance at the problem / K. Popadyuk; N. Vyatkina // Implementation of western experienes in school system of Ukraine. - K.: Abris, 2002. 184 p.; Yehorova O. Hromadyanske vykhovannya yak spetsialnyi napryam pozashkilnoyi osvity // Pedahohichni nauky Shidnoyevropeiskoho natsionalnoho universytetu imeni Lesi Ukrayinky. zb. nauk. st. - Lutsk, 2017. - Seriia 2 (351). - pp. 8-14.

${ }^{6}$ Yehorova O. Hromadyanske vykhovannya yak spetsialnyi napryam pozashkilnoyi osvity // Pedahohichni nauky Shidnoyevropeiskoho natsionalnoho universytetu imeni Lesi Ukrayinky. zb. nauk. st. - Lutsk, 2017. - Seriia 2 (351). - pp. 8-14.

7 The National Task Force on Civic Learning and Democratic Engagement / A Crucible Moment: College Learning and Democracy's Future // Association of American Colleges and Universities. - Washington D. C., 2012. - 98 p.; Yehorova O. 
It has been established that the set of program standards for teaching civic education, concluded by the members of the National Council for Civic Education (NCSS) is: "culture; time, continuity and variability; people, places, environment; individual development and identity; persons, groups and institutions; power, power structures and management; production, distribution and consumption; science, technology and society; global connections; civil ideals and practice" 8 . It should be added that this organization implements the College, Career and Civic Life (C3) program at social studies?.

The analysis of sources and information has shown that the content of civic education in the USA is changing at the present time. Thus, within the framework of the subject of civic education, the information on the various branches of government and on the history of America was also supplemented by further materials on the political system of the state and ways of influencing it, the cultural and global contexts of democracy and the principle of effective democracy has been added.Former Secretary of the United States Department of Education Arne Duncan and former Supreme Court Justice Sandra Day O'Connor stressed that in order for civic education to become more attractive and interesting, it should not remain at the level of "grandmother's civics but to go forward, develop in accordance with the requirements of time ${ }^{10}$. It was found that the

Hromadyanske vykhovannya yak spetsialnyi napryam pozashkilnoyi osvity // Pedahohichni nauky Shidnoyevropeiskoho natsionalnoho universytetu imeni Lesi Ukrayinky. zb. nauk. st. - Lutsk, 2017. - Seriia 2 (351). - pp. 8-14.

${ }^{8}$ National Council for the Social Studies (NCSS), http:/ / www.socialstudies.org/ about [access: 09.2016]; Yehorova O. Hromadyanske vykhovannya yak spetsialnyi napryam pozashkilnoyi osvity // Pedahohichni nauky Shidnoyevropeiskoho natsionalnoho universytetu imeni Lesi Ukrayinky. zb. nauk. st. - Lutsk, 2017. - Seriia 2 (351). pp. 8-14.

${ }^{9}$ National Council for the Social Studies (NCSS), http://www.socialstudies. org/about [access: 09.2016].

${ }^{10}$ Duncan A., O'Connor S. Civics Education, from http://www.thedailybeast. com/articles/2011/07/01/icivics-sandra-day-o-connor-and-arne-duncan-on-civicseducation-online.html [access: 09.2016]; Advancing Civic Learning and Engagement in 
present content was supplemented by the cultural and global contexts of democracy and democracy in action. Thus, civic education (upbringing) and involvement in democracy, that is, so-called active democracy, is often heard now and comes more in the focus. That is, the training and preparation of students for participation in social and democratic life, "providing opportunities for the development of knowledge of public education and skills ... through learning and practice" and integrating this knowledge into other subjects"11. Thus, events of active democracy are considered as priorities, which fully correlates with out-of-school education ${ }^{12}$. It was found that in America, civic education as a special field of non-formal education is conveyed through teaching civic education as a separate subject as well as though variety of out-of-school programs and activities.

In analyzing civic education as a prospective direction of out-ofschool education, it should be noted that in the United States particular attention is paid to the issue of its implementation. Thus, one of the unique program is learning through service, which integrates learning with projects is mandatory participation of high school students in community projects. As part of this program, secondary and high school students must work approximately 50 hours per year in community projects ${ }^{13}$. Former English teacher at Maryland School, and now researcher Kathy Megyeri shares her implementation strategies in her book, The History of Teaching through Service

Democracy: A Road Map and Call to Action / U.S. Department of Education, Office of the Under Secretary, Office of Postsecondary Education. - Washington D. C., 2012. 40 p.; Yehorova O. Hromadyanske vykhovannya yak spetsialnyi napryam pozashkilnoyi osvity // Pedahohichni nauky Shidnoyevropeiskoho natsionalnoho universytetu imeni Lesi Ukrayinky. zb. nauk. st. - Lutsk, 2017. - Seriia 2 (351). - pp. 8-14.

11 Bauer O. The Question of Nationalities and Social Democracy / O. Bauer // University of Minnesota Press. - Minneapolis-London, 2000. - 489 p.

12 Yehorova O. Hromadyanske vykhovannya yak spetsialnyi napryam pozashkilnoyi osvity // Pedahohichni nauky Shidnoyevropeiskoho natsionalnoho universytetu imeni Lesi Ukrayinky. zb. nauk. st. - Lutsk, 2017. - Seriia 2 (351). - pp. 8-14.

13 Yehorova O. Hromadyanske vykhovannya yak spetsialnyi napryam pozashkilnoyi osvity // Pedahohichni nauky Shidnoyevropeiskoho natsionalnoho universytetu imeni Lesi Ukrayinky. zb. nauk. st. - Lutsk, 2017. - Seriia 2 (351). - pp. 8-14. 
and Requirements in Maryland. element of teaching through ministry in the daily activities of teachers. Among them highlights: writing of works justifying the need for projects; developing an oral historical research project on community initiatives; writing letters of gratitude to parents and older people who have had a positive impact on the students; Letters to known people asking for things for charity fairs or auctions; Letters-tips for younger students about how to succeed in high school or college; preparing younger students for advice on children's books or writing children's books for them; donation of books to the primary school library; writing letters to editors and writing petitions to local, state and federal officials on local issues; study of works that include elements of civic education "Mice, People and Flowers for Elgerona", "King Lear", "Kill a Mocker"; different forms of reflection; attraction of funds and publication as a result of the use of elements of civic education [13].

Also, according to the National Nation Report Card, the following means are generally used: discussion o mainly use the following means: discussion of materials studied at school; writing short answers to questions, tests or riddles; role-playing games, simulating processes or playing scenes; group projects; work with additional literature; work in the library; discussion; Writing detailed answers to tasks; participation in debates or panel discussions; writing reports; preparing students for a class report; writing letters to express a position or help solve a community problem; a trip or a trip; invited speakers from the party ${ }^{14}$. It is revealed that also the following programs are included in the road map of engagement in democracy:

- The Facing History program, which promotes the involvement of students in civic engagement and critical thinking through the teaching of teachers in the study of cases of religious or racial persecution;

14 The Nation's Report Card / History, Geography, and Civics at Grade. - 2015, https://nces.ed.gov/whatsnew/commissioner/remarks2015/04_29_2015.asp [access: 09.2016]; The National Assessment of Educational Progress (NAEP), https://nces. ed.gov/nationsreportcard [access: 09.2016]. 
- Engineering Projects in Community Service (EPICS), in which engineering faculty students as well as students from 50 secondary schools in ten states work with community organizations to address community problems;

- Public Achievement (Coaching for Public Work) coaching program, where college students, graduates or secondary school teachers as community cohorts help primary and secondary school students in different teams to develop and implement joint projects or activities for the benefit of the school or community ${ }^{15}$;

- The Mikva Challenge program enables young people to express their views and participate in the decision-making process with the assistance of educators and leadership in the state or community ${ }^{16}$;

- The Network for Teaching Entrepreneurship (NFTE) program teaches teachers the basics of opening a business so that they have the opportunity to teach their students, while the business ideas of students are largely social in nature ${ }^{17}$;

- Civics 2.0 - educational program of interactive games in the field of civic education, familiar with the work of the government, various branches of government, work of courts, etc. ${ }^{18}$;

- Educational program or "Day of Constitution" ceremony, supported by the federal government, held annually on September 17 in each institution, in order to emphasize the importance of an active civic position and the importance of the Constitution ${ }^{19}$;

15 Public Achievement project, http:/ / www.augsburg.edu/sabo/what-we-do/ publicachievement [access: 09.2016].

16 The Mikva Model, http:/ / www.mikvachallenge.org [access: 09.2016].

17 The Network For Teaching Entrepreneurship, https://www.nfte.com [access: 09.2016].

18 ICivics, https:/ / www.icivics.org/ our-story [access: 09.2016].

${ }^{19}$ Constitution Day, http://www2.ed.gov/policy/fund/guid/constitutionday. html [access: 01.2017]; Advancing Civic Learning and Engagement in Democracy: A Road Map and Call to Action / U.S. Department of Education, Office of the Under Secretary, Office of Postsecondary Education. - Washington D. C., 2012. - 40p. 
- The National Student / Parent Mock Election Program, which uses a variety of activities, including "Democracy in Action", when students participate in election simulation and voter registration;

- "Kids Voting USA" program;

- UN Model Program, where events take place in youth city councils;

- The American Public Broadcasting project, which teaches the federal budget and online simulation games, such as the online budget game Hero Budget [20].

The US experience in the area of civic education was greatly beneficial for Ukrainian educators, which contributed to the development of cooperation between American and Ukrainian educators and public figures in the 1990s.

With the support and funding of the US government, several programs on civic education were implemented, events were being held. Among them are "Street Law", "Partners in Education" (Partners in Education) (PIE), etc. Thus, within the framework of the exchange program for teachers of history and social sciences disciplines, exchange visits of these teachers and school administrators were carried out aimed at familiarization with the best practices of civic education, studying history, etc.

It should be noted that, with the assistance of various funds and embassies, there were other programs and activities, including: CIVITAS and Education for Democracy programs, which supported teachers and democratization processes at school, the development of critical thinking and advanced pedagogical experience; trainings for teachers of social science disciplines; a program of mini-grants "Innovation in Education", which provided funding for trainings in the field of civic education, democracy in education; publishing of a newsletter for educators "Visnyk", etc. In addition, the following forms of work on civic education were introduced: debatable clubs, civic education centers in various regions of Ukraine (Kyiv, Poltava, Sevastopol, Tsyryupinsk, etc.). Such organizations as Nova Doba (Lviv), Teachers for Democracy and Partnership (Kyiv), have been 
created and actively research and develop civic education in Ukraine. It was established that the efforts of these organizations were published manuals and textbooks on civic education, in particular "Art to live in the community", "Civic education", "We are citizens of Ukraine", "We learn to be citizens". Also, electives in civic education are taught in separate schools in Ukraine. It should be noted that Ukrainian participants of the Teachers' Excellence Awards (TEA) program, secondary school educators funded by the US government, also had the opportunity during the late 90s of the twentieth century to participate in exchange programs with US peers. In the course of the study, the author as the coordinator of the Program for the Exchange of High School Students (SSEP), studied the issues of civic education as a special area of afterschool education. At the same time, it was possible to give an objective assessment of the importance of this experience, both for teachers and for students. During their visit to the United States and the contemplation of how American students respect their country, the flag, sang the anthem at schools, the students began to appreciate these attributes more and more at home, and feel themselves as citizens of their country.

In Ukraine, foreign experience in the field of civic education was theoretically and practically investigated quite actively. However, unfortunately, systematic work in the field of civic education in schools in Ukraine did not work out, despite the efforts of many activists and educators who really contributed greatly to the process of the birth, development and spread of civic education in Ukraine. Even in those schools where a civic education faculty was created, it was very difficult to keep this subject due to the excessive loading of the school curriculum, the lack of sufficient civic education manuals, a lack of training or a lack of teacher of civic education, etc.

It has been found that in the United States and Ukraine there similar problems with the content of civic education in schools. At the same time, training programs, project work and elements of civic education during non-formal programs compensate for these gaps and, moreover, they have the opportunity to monitor the situa- 
tion by monitoring the status of cases of civic education of students. For example, the 2010 National Report (Civics 2010) indicates a deterioration in the knowledge of pupils in civic education, compared with 1998. It was found that according to the report, $24 \%$ of 12 -class teachers and $23 \%$ of the 8 - the clerks have shown a sufficient or higher level of knowledge on the subject of civic education. At that time, $36 \%$ of students showed a lower level than the basic one. This is due to the insufficient amount of educational material on civic education. Less than half of the 12-class students are studying international topics and $2 / 3$ - certain important areas of the civic education of their country (such as the electoral system, the judicial system, the constitution) ${ }^{20}$. The report for 2014 did not show any significant changes, but only a slight improvement. So, $2 / 3$ of 8 th grade students pointed to the subject of civic education as a favorite.

To our mind, this influenced the fact that civic education disciplines are not available in every school due to the availability of programs and the need to prepare for the passing of tests. Therefore, half of the states do not require the completion of a course of civic education at the end of school, which affects such negative consequences as the poor level of knowledge about civic education of school graduates and universities.

Analyzing the recent information from the US Department of Education, we can assume that there is an intention to encourage schools and states to review school curricula and balance them with subjects such as history, civic education, economics, government programs. It is also planned to provide assistance to schools through OST programs. In Ukraine, the indicators of knowledge of civic education are even more disappointing given the unsystematic training of civic education, the crisis in society and education. O. Batishcheva in his paper "Behavioral Aspects and Differences in

20 The National Assessment of Educational Progress (NAEP), https://nces.ed. gov/nationsreportcard [access: 9.01.2017]; The National Task Force on Civic Learning and Democratic Engagement / A Crucible Moment: College Learning and Democracy's Future // Association of American Colleges and Universities. -Washington D. C., 2012. - 98 p. 
Values: An Analysis of the Status of Civic Consciousness in Ukrainian Youth" cites the results of a survey on understanding the features of civic education, their citizenship and civic attitude among high school students in secondary schools and undergraduate students in the framework of the project "Civic Education", conducted in the period from 09.2012 to 06.2013. When asked about the assessment of their own knowledge about the system of state authorities in Ukraine and the principles of democratic governance, $44 \%$ of respondents noted their knowledge as "good", 42.4\% - "satisfactorily", 10\% - "unsatisfactorily" and only 3.4\% of respondents indicated "excellent" 21. O. Batishcheva observes that relatively high indicators of awareness of self-awareness "correlate with the very small results of youth assessment of their activity". Interesting associations of young people on the question of the meaning of "state" for them through the term - "power" (9\%), "unity" (7\%), "nation, people" $(7 \%)$ and "order" (6\%). There were also such associations as "motherland", as well as negative ones - "evil", "control", "shame" $(2 \% \text { respectively })^{22}[21]$.

At the same time, a survey of the impact of the Orange Revolution on the national identity of young people conducted by us on the basis of McCoon's test with participants of the Youth Camp "School of Equal Opportunities" showed that the importance of the national identity of youth increased significantly after 2004. So, to the question: "Who am I?" the young people have increased their identification with the "ethnic group" and the share of the "private life" category, while the share of "positive and negative categories" has decreased. Also, categories became more active: for example, "a person who aspires to equality, freedom and love", "a fighter for the truth", "I love Ukraine", and others like that. All this confirms

${ }^{21}$ Batishcheva S. Povedinkovi aspekty ta rozbizhnosti u tsinnostyakh: analiz stanu hromadyanskoyi svidomosti u Ukrayinskoyi molodi. http://eprints.oa.edu.ua/2368 [access: 01.2017].

22 Batishcheva S. Povedinkovi aspekty ta rozbizhnosti u tsinnostyakh: analiz stanu hromadyanskoyi svidomosti u Ukrayinskoyi molodi. http://eprints.oa.edu. ua/2368 [access: 1.2017]. 
that revolutions contribute to the activity of the national consciousness of youth. But revolutions are radical measures, and gradual civic education from childhood is more effective.

Thus, the civic education of children and youth acquires a special significance and care in non formal education in Ukraine. The representatives of different regions of Ukraine, practicing teachers and scholars D. Desiatov, I. Kostiuk, A. Kucher, A. Panchenkov, S. Ratushniak, O. And Rostotskaya, S. Sayenko, G. Senkovska, L. Seredyak, A. Kovtonyuk, O. Shiyan and others adapted foreign experiences though textbooks, projects and other activities on civic education and upbringing in school and out-of-school. As a result of this process, programs and teaching and learning materials and guidelines on teaching and learning of civic education were created, in particular, "The Concept of Civic Education of Ukraine", authored by T. Aslamova, T. Buck, P. Verbitskaya, O. Voitenko, V. Bortnikov, T. Ginetova, L. Dukh, O. Zheliba, V. Kononenko, T. Ladichenko, T. Meleschenko, M. Mykhailychenko, G. Mikhailovich, S. Poznyak, O. Pometun, O. Salat, N. Syik, Ye Sinyova, N. Sophia, O. Suslova, V. Tereshchenko, S. Terno and others23.

It should be noted that many conferences and seminars on issues of civic education through the study of world experiences in Ukraine. A major contribution to the study of American experience was the All-Ukrainian Scientific and Practical Conference "American Philosophy of Education through the Eyes of Ukrainian Researchers", organized by the Ministry of Education and Science of Ukraine, the Academy of Pedagogical Sciences with the financial support of the PAS,US Embassy in Ukraine on December 22, 2005. As part of the development of the use of American experience, the "Anthology of adapted experience or the reason of programs of educational exchanges," which included articles by educators, alumni of exchange programs funded by the Government of the

${ }^{23}$ Yehorova O. Hromadyanske vykhovannya yak spetsialnyi napryam pozashkilnoyi osvity // Pedahohichni nauky Shidnoyevropeiskoho natsionalnoho universytetu imeni Lesi Ukrayinky. zb. nauk. st. - Lutsk, 2017. - Seriia 2 (351). - pp. 8-14. 
United States, which elaborated American experience and covered strategies for its adaptation to Ukrainian educational space ${ }^{24}$.

One of the examples of successful adaptation of the American experience of civic education in non-formal education in Ukraine is the annual public action of secondary school students "I am a Citizen", which has been conducted throughout Ukraine for about ten years now by All-Ukrainian Association of Teachers of History and Civics "Nova Doba" (Lviv). The goal of the project is to create meaningful social projects by students who solve a certain actual problem of their local community. The names of some social projects on the public action of students in Ukraine "Citizen 2015" are very eloquent and indicate a great variety of social problems and the creative search for their solutions: "Causes of pollution of the village of Kornin by household waste", "Creation of a complex nature monument "Kurgan", "The Center for Intellectual and Legal Growth" Perspective", "The Name of the Hero lives in the street name", "I am a person, then I have the right", "With faith in the defenders! With Hope for the World! With Love to Ukraine! "Homeland begins with you" 25 . Other programs contributing to the formation of citizenship are the following activities "Nova Doba": the creation of youth councils at local councils, the "Youth Act" project, SOS - Historical monument - a competition for projects aimed at preserving the historical heritage of the area ${ }^{26}$. It should be noted that, from Nova Doba organization's example, we can see the effective use of American experience in civic education in OST activities of students, adaptation to Ukrainian conditions and the development of their unique programs on civic education, in particular tolerance and critical thinking, events "Democracy in Action" , "Deliberation in Democracy", "I am a Citizen".

${ }^{24}$ Ischenko Y. Philosofsky analiz pytan adaptatsiyi zakordonnoho osvityanskoho dosvidu // Antolohiya adaptovanoho dosvidu abo dlya choho isnuyut program osvitnikh obminiv. - Rivne, 2004. - pp. 9-14.

25 Nova Doba, http:/ / www.novadoba.org.ua [access: 11.2017].

${ }^{26}$ Nova Doba, http:/ / www.novadoba.org.ua [access: 11.2017]. 
The civic orientation of the educational process makes it possible to really influence the acquisition of the competencies of students necessary for life in class and outside school, facilitates life in society and promotes identification of their inclinations, talents, manifestation of conscious civic activity and position. For the effective implementation of the concept of civic education in the nonformal sector and for the improvement of the process of civic education, it is necessary to: democratize the afterschool educational space; training and increasing the professional qualifications of teachers of afterschool educational institutions regarding civic education. The Guardian of Democracy report provides guidance to schools and educators, including those that may apply to Ukrainian institutions: to revitalize civil education by discussing events; use successful practices; encourage students to participate in school and out-of-school community events and programs ${ }^{27}$.

Summarizing the above, it should be noted that civic education is one of the priority areas of education in the United States and in Ukraine. It has long historical roots and its significance is due to the fact that the out-of-school programs for education for democratic citizenship, organized activities and activities in out-of-school establishments are an effective means of building the abilities and competences necessary for community living. After all, such practical activity of youth is more flexible, implemented in the local community and is of interest to young people. Thus, civic education in after-school education in the United States is considered and justified as a systematic object in its substantive and procedural aspects, which aims to form national, universal human values, social activity, competencies required by the person in the 21st century. Among them - the integration of knowledge, skills and values in action; the ability of critical thinking, the skills of "collective action": the skills of achieving a compromise and mutual respect; solving public issue involving different parties; orientation in political systems and processes.

${ }^{27}$ Gould J. Guardians of Democracy: The Civic Mission of Schools / J. Gould / / Philadelhia: Lenore Annerberg Institute of Civics of the Annenberg Public Policy Center, Campaign for the Civic Mission of Schools. - Philadelhia, 2011. - 159 p. 
Consequently, modern pedagogical forms of civic education contribute to the development of social competences and active participation in social life, develop the skills of critical thinking, discussion, cooperation, negotiation, decision-making, interaction, competencies necessary for life, facilitates life in society and contributes to revealing their inclinations, talents, and conscious civic activity and position.

Throughout the OST history in America, the theme of civic education was a red thread, and today OST programs around the world could be of use in this regard. So, given the schools workload, OST establishments can more actively implement elements of civic education in their programs and educate citizens also by OST teachers' own example. Therefore, we consider it expedient to carry out further theoretical and methodological development of the issue of civic education as prospective direction of after-school education.

\section{References}

The National Task Force on Civic Learning and Democratic Engagement / A Crucible Moment: College Learning and Democracy's Future // Association of American Colleges and Universities. - Washington D. C., 2012. - 98 p.

Gould J. Guardians of Democracy: The Civic Mission of Schools / J. Gould // Philadelhia: Lenore Annerberg Institute of Civics of the Annenberg Public Policy Center, Campaign for the Civic Mission of Schools. - Philadelhia, 2011. - 159 p.

Advancing Civic Learning and Engagement in Democracy: A Road Map and Call to Action / U.S. Department of Education, Office of the Under Secretary, Office of Postsecondary Education. - Washington D. C., 2012. - 40p.

Popadyuk K. Specificity of the adaptation of the American information in the sphere of civic education and upbrining/ K. Popadyuk // Actual problems of civic education and upbrining: Ukrainian and foreign experiences: materials of the I scientific and practical conference, 19 June 2013. / National. Univ. „Ostrozka Akademia", non-governmental organization "Center for Democratic Leadership"; [Відп. Ed. O. S. Batishcheva]. - Ostrog, 2013. - 234 p.

Popadyuk K. The formation of the civic education in Ukraine. A glance at the problem / K. Popadyuk; N.Vyatkina // Implementation of western experienes in school system of Ukraine. - K. Abris, 2002. - 184 p.

Bauer O. The Question of Nationalities and Social Democracy / O. Bauer // University of Minnesota Press. - Minneapolis-London, 2000. - 489 p. 
The Mikva Model, http://www.mikvachallenge.org [access: 09.2016].

National Council for the Social Studies (NCSS), http://www.socialstudies.org/ about [access: 09.2016].

Duncan A., O'Connor S. Civics Education, from http://www.thedailybeast.com/ articles/2011/07/01/icivics-sandra-day-o-connor-and-arne-duncan-on-civicseducation-online.html [access: 09.2016].

Ponomarenko L. Mental'nist yaderni tsinnosti ta philosophia osvity $\mathrm{v}$ Ukrayini s SshA / L. Ponomarenko // Amerykanska philosophia osvity ochyma ukrayinskykh doslidnykiv / Materialy Vseukrayinskoyi naukovo-practychnoyi conferentsiyi 22 hrudnya 2005. - Poltava: POIPPO, 2005. - pp. 142-148.

Sukhina B., Shaparenko O. Pro dosvid SShA u horomadyanskomu vykhovanni / B. Sukhina, O. Shaparenko // Amerykanska philosophia osvity ochyma ukrayinskykh doslidnykiv / Materialy Vseukrayinskoyi naukovo-practychnoyi conferentsiyi 22 hrudnya 2005. - Poltava: POIPPO, 2005. - pp. 187-193.

Ischenko Y. Philosofsky analiz pytan adaptatsiyi zakordonnoho osvityanskoho dosvidu // Antolohiya adaptovanoho dosvidu abo dlya choho isnuyut program osvitnikh obminiv. - Rivne, 2004. - pp. 9-14.

Megyery K. History of the Service-Learning It Requirement in Maryland. - University of Nebraska Omaha, 1997. -5 p.

The Nation's Report Card / History, Geography, and Civics at Grade. - 2015, https:/ / nces.ed.gov/whatsnew/commissioner/remarks2015/04_29_2015.asp [access: 09.2016].

The National Assessment of Educational Progress (NAEP), https://nces.ed.gov/ nationsreportcard [access: 09.2016].

Yehorova O. Hromadyanske vykhovannya yak spetsialnyi napryam pozashkilnoyi osvity // Pedahohichni nauky Shidnoyevropeiskoho natsionalnoho universytetu imeni Lesi Ukrayinky. zb. nauk. st. - Lutsk, 2017. -Seriia 2 (351). - pp. 8-14.

The Network For Teaching Entrepreneurship, https://www.nfte.com [access: 09.2016].

Public Achievement project, http://www.augsburg.edu/sabo/what-we-do/publi cachievement [access: 09.2016].

ICivics, https:// www.icivics.org/our-story [access: 09.2016].

Teaching History, http://teachinghistory.org/digital-classroom/tech-for-teachers/ 25813 [access: 01.2017].

Batishcheva S. Povedinkovi aspekty ta rozbizhnosti u tsinnostyakh: analiz stanu hromadyanskoyi svidomosti u Ukrayinskoyi molodi. http:/ / eprints.oa.edu.ua/ 2368 [access: 01.2017].

Nova Doba, http://www.novadoba.org.ua [access: 11.2017].

The National Assessment of Educational Progress (NAEP), https://nces.ed.gov/ nationsreportcard [access: 9.01.2017].

Constitution Day,http://www2.ed.gov/policy/fund/guid/constitutionday.html [access: 01.2017]. 